\title{
PENGARUH IMPLEMENTASI BAURAN \\ PEMASARAN JASA TERHADAP KEPUTUSAN \\ WISATAWAN MENGUNJUNGI OBJEK WISATA \\ PULAU PASUMPAHAN
}

\author{
Fandi Pranata Hidayat, Aminar Sutra Dewi \\ Sekolah Tinggi Ilmu Ekonomi KBP \\ fandipranata37@yahoo.co.id
}

\begin{abstract}
The development of tourism business can have a positive impact in the effort to contribute to the country's foreign exchange earnings, increasing business opportunities and new jobs, increasing government and community revenue. The purpose of this study is to determine whether the influence of the implementation of service marketing mix (product, price, place, promotion, people, process and physical evidence) affect the decision of tourists visiting the tourist object of Pasumpahan island. In this study this population refers to tourists who have visited the tourist object Pasumpahan Island, samples taken as many as 100 respondents using convenience sampling techniques. Data analysis techniques used are observations, questionnaires and documentation. Method used in this study is multiple linear regression analysis, the results obtained show that the product, price, place, process has no significant effect on the purchase decision, while promotion, people and physical evidence significantly influence the purchase decision.
\end{abstract}

Keywords: Product, Price, Promotion, Place, People and Physical Evidence influence the purchase decision.

\section{PENDAHULUAN}

Perkembangan bisnis pariwisata mampu memberikan dampak positif dalam upaya memberikan sumbangan terhadap penerimaan devisa negara, meningkatkan kesempatan usaha dan lapangan kerja baru, meningkatkan pendapatan pemerintah dan masyarakat. Sektor pariwisata juga mampu menghidupkan perekonomian masyarakat, baik dalam sektor jasa maupun industri barang-barang kerajinan dan masakan khas tadisional lainnya, hal ini meunjukan bahwa sektor pariwisata merupakan penyumbang devisa negara terbanyak selain ekspor minyak dan gas. (Aisyah \& Edwar, 2012)

Keputusan wisatawan adalah tahap proses keputusan diamana pengunjung secara aktual malakukan pemilihan terhadap objek. Sehingga dapat juga di katakan bahwa keputusan berkunjung wisatawan merupakan suatu proses dalam menentukan kunjungan dan melakukan kegiatan perjalanan ke suatu objek wisata.

Semenjak berlakunya Undang-undang Otonomi Daerah mendorong masing-masing provinsi untuk mencari berbagai sumber pembiayaan bagi daerahnya masing-masing, era otonomi daerah menuntut kemandirian daerah memajukan daerahnya masing-masing dalam mengelola aset-aset daerah yang dimilikinya, salah satu yang dilakukan oleh pemerintah daerah setempat adalah pengembangan perekonomian daerah dalam bidang jasa yaitu memajukan sektor pariwisata dengan hal ini maka dapat meningkatkan pendapatan pemerintah dan 
berkontribusi langsung terhadap peningkatan devisa negara. Hal ini mendorong terciptanya kreasi dan inovasi dalam jasa pariwisata untuk dapat menarik para wisatawan.

Keputusan wisatawan untuk memilih sebuah objek wisata pada dasarnya merupakan salah satu bentuk pengambilan keputusan. Pada umumnya manusia bertindak lebih teliti dalam mempertimbangkan segala resiko dari informasi yang tersedia sebelum melakukan sebuah keputusan. Setelah itu pihak pengunjung mulai mengevaluasi pilihan yang akan di kunjungi sesuai dengan kebutuhan dan keinginan dalam mendapatkan sebuah hiburan. Keputusan berkunjung merupakan bagian dari perilaku konsumen yang berisikan serangkaian tahapan penting hingga pada akhirnya melakukan sebuah keputusan untuk mengunjungi sebuah objek wisata.

Dengan memberikan jasa yang sesuai dengan harapan konsumen dan menerapkan program bauran pemasaran pihak pengelola pariwisata diperkirakan dapat meningkatkan kunjungan wisatawan ke objek wisata yang ada di pulau pasumpahan. Apabila wisatawan mempersepsikan bauran pemasaran jasa meliputi Product (Produk), produk yang di pasarkan perusahaan haruslah sesuai dengan kebutuhan konsumen. Price (Harga), penetapan harga merupakan salah satu kunci penting dalam memasarkan produk. Promotion (Promosi), perusahaan harus aktif dalam mempromosikan produk/jasa nya kepada pihak konsumen sehinnga terjadi suatu daya tarik. Place (Tempat), pihak perusahaan harus mampu memberikan suasan yang menarik sehingga menciptakan suatu kenyamanan bagi konsumen. PhysicalEvidence (Kondisi Fisik), merupakan kondisi fisik yang berhubungan dengan kesuksesan dan dapat mempengaruhi keputusan konsumen untuk berkunjung. Process (Proses), merupakan upaya yang di lakukan untuk dapat melakukan kegiatan dalam memenuhi kebutuhan pengunjung secara tepat. People (Orang), dengan ada nya unsur manusia untuk dapat memperkuat serta meyakinkan secara langsung kepada konsumen sesuai dengan harapannya.

Proses keputusan pembelian konsumen merupakan salah satu bagian dari perilaku konsumen (consumer behavior) yang tercipta. Keputusan pembelian adalah sikap dari hasil pemutusan yang ditetapkan oleh pembeli setelah mempertimbangkan jenis produk, merek, kuantitas, waktu, produsen, tenaga penjual, dan metode pembayaran untuk memenuhi kebutuhan dan keinginan.

Enzyklopädie(2015)menyatakan :Keputusan membeli seseorang yang asalnya dipengaruhi oleh lingkungan, kebudayaan, keluarga, dan sebagainya, akan membentuk suatu sikap pada diri individu, kemudian melakukan pembelian.

Berdasarkan pendapat dari beberapa ahli di atas bahwa keputusan pembelian merupakan proses keputusan di mana konsumen benar-benar memutuskan untuk menggunakan salah satu produk/jasa diantara berbagai macam alternatif pilihan.

Kusuma, (2015)Mengemukakan indikator untuk mengukur keputusan pembelian sebagai berikut :

1. Keinginan untuk menggunakan produk

2. Keinginan untuk membeli produk

3. Memproritasakan pembelian suatu produk

4. Kesediaan untuk berkorban (waktu, biaya dan tenaga) mendapatkan suatu produk 
Djatikusuma,(2014)menyatakan bahwa indikator keputusan pembelian adalah buy or not buy berhubungan dengan keyakinan dalam membeli danwould not expect any problem yaitu harapan untuk tidak mendapatkan masalah atau resiko, serta pertimbangan untuk mendapatkan manfaat dari produk.

Pengertian bauran pemasaran menurut Pinaringsih,(2015)adalah seperangkat alat pemasaran yang digunakan perusahaan untuk terus menerus mencapai tujuan pemasarannya di pasar sasaran. Bauran pemasaran adalah merupakan alat bagi pemasar yang terdiri atas berbagai unsur suatu program pemasaran yang perlu dipertimbangkan agar implementasi strategi pemasaran dan positioning yang ditetapkan dapat berjalan sukses.

Bauran pemasaran merupakan tool atau alat bagi pemasar yang terdiri atas berbagai elemen suatu program pemasaran yang perlu dipertimbangkan agar implementasi strategi pemasaran dan positioning yang ditetapkan dapat berjalan sukses. Ada empat komponen yang tercakup dalam kegiatan bauran pemasaran, yaitu produk (product), harga (price), promosi (promotion) dan distribusi (place). Pendekatan pemasaran 4P tradisional tersebut berhasil dengan baik untuk pemasaran barang, tetapi 4P saja tidak cukup buat pemasaran jasa.Diana \&Dhiba, (2014)mengusulkan 3P tambahan untuk pemasaran jasa, yaitu orang (people), bukti fisik (Physical Evidence) dan Proses (Process).

(Diana \& Dhiba, 2014) Model bauran pemasaran 4P ditambah dengan 3P yaitu orang (Participants), Proses (Process) dan Bukti Fisik (Physical Evidence). Bauran pemasaran yang diperluas tersebut karena pertimbangan kebutuhan akan keragaman ekonomi jasa yang meliputi perusahaan jasa maupun perusahaan manufaktur yang bagi mereka jasa dianggap penting. Konsep bauran pemasaran yang diperluas ini mencerminkan unsur-unsur sebagai berikut: Produk (product), Harga (price), Promosi (promotion) dan Distribusi /Lokasi (place), ditambah tiga unsur menurut Booms dan Bitner tersebut diatas yakni : Orang (participants), Proses (process), dan Bukti Fisik (Physical Evidence)

Keunggulan kompetitif perusahaan berkaitan dengan kemampuan perusahaan untuk memenangkan persaingan pasar melalui cara-cara yang khas yang tidak dimiliki oleh perusahaan lain (Lita, 2010). Keunggulan bersaing (competitive advantage) merupakan strategi formulasi perusahaan yang dirancang untuk mencapai peluang-peluang yang menguntungkan dan tidak dapat ditiru oleh pesaing untuk memaksimumkan pengembalian investasi perusahaan, yang dapat dilakukan melalui strategi inovasi, peningkatan kualitas, dan strategi pengurangan biaya.Denganmemberikan jasa yang sesuai dengan harapan konsumen dan menerapkan program bauran pemasaran pihak pengelola pariwisata diperkirakan dapat meningkatkan kunjungan wisatawan ke objek wisata Pulau Paumpahan. Maka didapat hipotesis produk, harga, promosi, tempat, orang, proses, dan bukti fisik.Penelitian Pinaringsih, (2015)dengan penelitian pengaruh bauran pemasaran terhadap keputusan berkunjung wisatawan di museum geologi bandung dimnana hasil penelitian berpengaruh positif dan signifikan terhadap keputusan berkunjung di museum geologi bandung.Penelitian Pradita, (2012) dengan penelitian pengaruh bauran pemasaran terhadap keputusan berkunjung di objek wisata bukit cinta ambarawa dengan hasil penelitian secara simultan produk, harga, promosi, tempat, people, proses, pelayanan memiliki pengaruh signifikan.Penelitian Lita, (2010)dengan penelitian pengaruh implementasi bauran pemasaran jasa terhadap proses keputusan wisatawan mengunjungi objek wisata di kota padang, dari hasil 
penelitian dapat di simpulkan bahwa bauran pemasaran jasa meliputi produk, harga, promosi, tempat, bukti fisik, proses dan personel berpengaruh secara silmultan dan parsial terhadap proses keputusan wisatawan mengunjungi objek wisata.

\section{METODE PENELITIAN}

Jenis penelitian yang dilakukan dalam penelitian ini adalah penelitian kuantitatif, menurut Malardy \& Sari, (2015) penelitian kuantitatif adalah penelitian yang dilakukan terhadap sejumlah individu atau unit analisis, sehingga ditemukan fakta atau keterangan secara faktual mengenai gejala suatu kelompok atau perilaku individu dan hasilnya dapat digunakan sebagai bahan pembuatan rencana atau pengambilan keputusan. Penelitian kuantitatif ini merupakan studi yang bersifat survei menggunakan kuesioner sebagai alat pengumpulan data.

Populasi dalam penelitian ini adalah pengunjung pulau pasumpahan dimana jumlahnya tidak diketahui. maka diketahui hipotesis yaitu, produk, harga, tempat, promosi, orang, proses dan kondisi fisik.

Sampel dalam penelitian ini adalah pengunjung pulau pasumpahan. Karena jumlah populasi tidak diketahui secara pasti maka untuk menghemat waktu, tenaga, dan biaya maka ukuran sampel (jumlah responden) ditentukan.

$$
\mathrm{n}=\frac{\left[Z_{\alpha / 2}\right]^{2} \mathrm{p} \cdot \mathrm{q}}{\mathrm{e}^{2}}
$$

Dalam penelitian ini digunakan tingkat ketelitian $(\alpha) 5 \%$, tingkat kepercayaan $95 \%$ sehingga diperoleh nilai $Z=1,96$. Tingkat kesalahan ditentukan sebesar $10 \%$. Sementara itu, probabilitas kuesioner benar (diterima) atau salah (ditolak) masing-masing adalah 0,5. Dengan memasukkan ke dalam persamaan di atas, maka diperoleh:

$$
\begin{aligned}
& n=\frac{(1,96)^{2} 0,5 \cdot 0,5}{0,1^{2}} \\
& n=\frac{0,9604}{0,01} \\
& n=96,04=96
\end{aligned}
$$

Pada perhitungan yang dihasilkan diperoleh sampel minimum 96, tetapi penulis membulatkan menjadi 100 orang.

Pengumpulan data penelitian dilakukan dengan cara menggunakan metode sebagai berikut:

\section{Wawancara}

Penulis mengadakan komunikasi secara langsung dengan pemilik dan gaet pulau pasumpahan yang berhubungan langsung dengan objek penelitian.

2. Observasi

Penulis mengadakan pengamatan langsung agar dapat memperoleh gambaran tentang keadaan pulau pasumpahan. 
Tabel 1

Definisi Operasional

\begin{tabular}{|l|l|l|}
\hline Variabel & Devenisi & Indikator \\
\hline Implementasi Pemasaran & Merupakan suatu proses pemasaran & 1. Produk \\
& dan rencana yang sudah disusun & 2. Harga \\
& menjadi tindakan pemasaran untuk & 3. Tempat \\
& mencapai pasar sasaran. & 4. Promosi \\
& & 5. Orang \\
& & 6. Proses \\
\hline Keputusan wisatawan & Keputusan yang konsumen lakukan & 7. Lingkungan Fisik \\
& berkaitan dengan berwisata adalah & 2. Pencarian informasi \\
& keputusan wisatwan untuk & 3. Evaluasi Alternatif \\
& mengunjungi objek wisata. Keputusan & 4. Keputusan pembelian \\
& wisatawan untuk memilih objek wisata & 5. Perilaku pasca pembelian \\
& pada dasarnya merupakan salah satu & \\
& bentuk pengambilan keputusan. & \\
\hline
\end{tabular}

\section{Teknis Analisis Data}

\section{Uji validitas}

Uji validitas digunakan untuk mengukur sah atau valid tidaknya suatu kuesioner. Uji validitas merupakan ukuran yang menunjukkan tingkat kevalidan suatu intrumen atau kuisioner.hasil pengolahan menggunakan program SPSS pada tabel item total statistik di kolom corrected item total correlation. Validnya ditentukan dari nilai koefisien korelasi yang dihasilkan besar dari 0,30 dan dapat digunakan untuk selanjutnya.

\section{Uji Reliabilitas}

Menurut Aisyah \& Edwar, (2012)Reabilitas sebenarnya adalah alat untuk mengukur suatu kuesioner yang merupakan indikator dari suatu variabel atau kontruk.item-item pertanyaan yang valid yang dilihat dari nilai cronbach alpha yang dihasilkan $>0,60$.

\section{Analisis Deskriptif}

Analisis ini bermaksud untuk menggambarkan karakteristik masingmasing variabel penelitian. Hasil pengolahan data dalam analisis deskriptif kemudian di deskripsikan dengan tujuan menggunakan proporsi jawaban respoden terhadap variabel penelitian.Menurut Aisyah \& Edwar, (2012)total capaian respoden merupakan suatu ukuran untuk menghitung masing-masing kategori jawaban dari deskriptif variabel, maka dapat dihitung dengan mengguanakan rumus:

\section{Asumsi Klasik}

$$
T C R=\frac{\mathrm{Rs}}{\mathrm{n}} \times 100
$$

Keterangan:

$$
\begin{array}{rll}
\mathrm{TCR} & = & \text { Tingkat Capaian Responden } \\
\mathrm{Rs} & = & \text { Rata-rata skor jawaban responden (rerata) } \\
\mathrm{n} & = & \text { Nilai skor jawaban }
\end{array}
$$

Uji asumsi klasik juga tidak perlu dilakkan untuk analisis regresi linear yang bertujuan untuk menghitungkan nilai pada variabel tertentu.Analisis dapat dilakukan tergantung pada data yang ada. Sebagai contoh, dilakukan analisis terhadap samua uji asumsi klasik, lalu dilihat mana yang tidak memenuhi persyaratan. Kemudian dilakukan perbaikan pada uji tersebut dan setelah 
memenuhi persyaratan, dilakukan pengujian pada uji yang lain, terdapat 3 pengujian asumsi klasik sebagai berikut:

1. Uji normalitas

2. Uji heteroskedastisitas

3. Uji multikolonieritas

\section{Analisis Regresi Linear Berganda}

Regresi Linear Berganda merupakan salah satu teknik analisis data yang sering digunakan oleh seorang peneliti yang menggunakan pendekatan penelitian kuantitatif.

Regresi Linear Berganda dinotasikan dalam persamaan berikut ini:

$$
\mathrm{Y}=\mathrm{a}+b_{1} X_{1}+b_{2} X_{2}+b_{3} X_{3}+b_{4} X_{4}+b_{5} X_{5}+b_{6} X_{6}+b_{7} X_{7}+\mathrm{e}
$$

\section{HASIL DAN PEMBAHASAN \\ Uji Validitas}

Tabel 2

Uji Validitas Variabel Terikat Keputusan Pembelian (Y)

\begin{tabular}{cccc}
\hline Variable & \multicolumn{1}{c}{ Pernyataan } & Uji Validitas & Keterangan \\
\hline Keputusan & 1. $\begin{array}{l}\text { Saya memilih Bot/Kapal yang besar dan } \\
\text { memliki fasilitas keamanan yang lengkap } \\
\text { menuju pulau pasumpahan }\end{array}$ & 0.553 & Valid \\
& $\begin{array}{l}\text { 2. } \\
\text { Lokasi yang strategis menjadi } \\
\text { pertimbangan saya dalam memilih } \\
\text { keputusan berkunjung ke pulau } \\
\text { pasumpahan }\end{array}$ & 0.496 & Valid \\
& $\begin{array}{l}\text { 3. } \begin{array}{l}\text { Saya mencari tahu melalui iklan sebelum } \\
\text { memutuskan memilih berkunjung kepulau } \\
\text { pasumpahan }\end{array} \\
\text { 4. Setiap orang yang sudah berkunjung kepulat } \\
\text { pasumpahan selalu bercerita tentang pulau } \\
\text { pasumpahan }\end{array}$ & 0.415 & Valid \\
5. Saya tidak memerlukan perantara untuk \\
$\begin{array}{l}\text { menyewa perahu } \\
\text { 6. Saya memilih perahu yang ada tempat } \\
\text { duduk nya supaya aman di perjalanan }\end{array}$ & 0.457 & Valid \\
& $\begin{array}{l}\text { 7. Saya akan pergi kepulau pasumpahan } \\
\text { untuk hari berikut nya }\end{array}$ & 0.524 & Valid \\
\hline
\end{tabular}

Sumber : Pengolahan Data primer 2018

Berdasarkan tabel 2 dapat dilihat bahwa semua item pernyataan dinyatakan valid karena $\mathrm{r}$ tabel pada semua item pernyataan $\mathrm{r}$ kritis berada diatas 0.30 . Sehingga semua item tidak ada yang dihilangkan. 
Tabel 3

Uji Validitas Variabel Bebas Produk $\left(\mathrm{X}_{1}\right)$

\begin{tabular}{|c|c|c|c|}
\hline Variable & Pernyataan & Uji Validitas & Keterangan \\
\hline \multirow[t]{6}{*}{ roduk } & $\begin{array}{l}\text { 1. Pemandangan pulau pasumpahan sangat } \\
\text { indah dan ombak hijau laut yang lepas }\end{array}$ & 0.362 & Valid \\
\hline & $\begin{array}{l}\text { 2. Saya melihat pemandangan bawah laut } \\
\text { pulau yang sangat indah dan dihiasi } \\
\text { dengan terumbu karang }\end{array}$ & 0.462 & Valid \\
\hline & $\begin{array}{l}\text { 3. Selain berenang ada bukit yang terjal } \\
\text { untuk melihat ke indahan pulau } \\
\text { pasumpahan dan sekitar nya }\end{array}$ & 0.482 & Valid \\
\hline & $\begin{array}{l}\text { 4. Disediakan peralatan menyelam seperti, } \\
\text { kaca mata selam, telapak kaki itik untuk } \\
\text { mempermudah berenang dan camera anti } \\
\text { air }\end{array}$ & 0.473 & Valid \\
\hline & $\begin{array}{l}\text { 5. Disediakan nya benen karet buat } \\
\text { pengunjung yang ingin berenang/mandi- } \\
\text { mandi }\end{array}$ & 0.433 & Valid \\
\hline & $\begin{array}{l}\text { 6. Di sekitar pulau pasumpahan di sediakan } \\
\text { pondok-pondok tempat beristirahat }\end{array}$ & 0.393 & Valid \\
\hline
\end{tabular}

Berdasarkan tabel 3 dapat dilihat bahwa semua item pernyataan dinyatakan valid karena $r$ tabel pada semua item pernyataan $r$ kritis berada diatas 0.30 . Sehingga semua item tidak ada yang dihilangkan.

\section{Tabel 4}

Uji Validitas Variabel Bebas Harga $\left(\mathbf{X}_{2}\right)$

\begin{tabular}{|c|c|c|c|}
\hline Variable & Pernyataan & Uji Validitas & Keterangan \\
\hline \multirow[t]{4}{*}{ Harga } & $\begin{array}{l}\text { 1. Harga sewa bot/kapal bisa di nego } \\
\text { tergantung banyak atau sedikit nya } \\
\text { penumpang yang akan di antar kepulau } \\
\text { pasumpahan }\end{array}$ & 0.511 & Valid \\
\hline & $\begin{array}{l}\text { 2. Harga paket tour pulau pasumpahan bisa } \\
\text { dikondisikan tidak tergantung banyak orang } \\
\text { nya dan dikasih free snack dan makan }\end{array}$ & 0.493 & Valid \\
\hline & $\begin{array}{l}\text { 3. Harga tiket masuk pulau bisa di diskon jika } \\
\text { rombongan nya banyak }\end{array}$ & 0.388 & Valid \\
\hline & $\begin{array}{l}\text { 4. Harga sewa bot/kapal yang saya tumpangi } \\
\text { dengan harga yang sangat terjangkau }\end{array}$ & 0.323 & Valid \\
\hline
\end{tabular}


Tabel 5

Uji Validitas Variabel Bebas Tempat $\left(\mathbf{X}_{3}\right)$

\begin{tabular}{|c|c|c|c|}
\hline Variable & Pernyataan & Uji Validitas & Keterangan \\
\hline \multirow[t]{4}{*}{ Tempat } & $\begin{array}{l}\text { 1. Pulau pasumpahan memiliki lokasi yang } \\
\text { strategi yaitu memiliki pantai dan } \\
\text { perbukitan yang tinggi sehingga bisa } \\
\text { melihat keindahan di sekitar pulau }\end{array}$ & 0.480 & Valid \\
\hline & $\begin{array}{l}\text { 2. Jarak antara dermaga sungai pisang dengan } \\
\text { pulau pasumpahan tidak terlalu jauh dan } \\
\text { ombak laut nya tenang sehingga bot tidak } \\
\text { terasa oleng }\end{array}$ & 0.494 & Valid \\
\hline & $\begin{array}{l}\text { 3. Pulau pasumpahan memiliki hamparan } \\
\text { pasir putih yang berpadu dengan air laut } \\
\text { yang bening }\end{array}$ & 0.429 & Valid \\
\hline & $\begin{array}{l}\text { 4. Perahu yang saya tumpangi tidak sulit } \\
\text { mencari nya }\end{array}$ & 0.432 & Valid \\
\hline
\end{tabular}

Tabel 6

Uji Validitas Variabel Bebas Promosi $\left(\mathbf{X}_{4}\right)$

\begin{tabular}{clcc}
\hline Variable & \multicolumn{1}{c}{ Pernyataan } & Uji Validitas & Keterangan \\
\hline Promosi & $\begin{array}{l}\text { 1. } \\
\text { Informasi pulau pasumpahan bisa dilihat } \\
\text { dari internet }\end{array}$ & 0.380 & Valid \\
& $\begin{array}{l}\text { 2. } \begin{array}{l}\text { Nelayan yang sering mampir ke pulau } \\
\text { pasumpahan dapat memberikan informasi } \\
\text { tentang ke indahan pulau }\end{array} \\
\text { 3. Informasi tentang pulau pasumpahan yang } \\
\text { diberikan lewat brosur dan baliho cukup } \\
\text { informative }\end{array}$ & 0.586 & Valid \\
& $\begin{array}{l}\text { 4. Saya tertarik pergi kepulau pasumpahan } \\
\text { karena pengaruh teman-teman yang sudah } \\
\text { pergi kepulau tersebut }\end{array}$ & 0.533 & Valid \\
\hline
\end{tabular}

Sumber : Pengolahan Data primer 2018

Berdasarkan tabel 6 dapat dilihat bahwa semua item pernyataan dinyatakan valid karena $r$ tabel pada semua item pernyataan $r$ kritis berada diatas 0.30. Sehingga semua item tidak ada yang dihilangkan.

\section{Tabel 7}

Uji Validitas Variabel Bebas Orang $\left(\mathrm{X}_{5}\right)$

\begin{tabular}{crlcc}
\hline Variable & \multicolumn{1}{c}{ Pernyataan } & Uji Validitas & Keterangan \\
\hline Orang & 1. & $\begin{array}{l}\text { Sebelum bot/kapal berangkat, pengemudi } \\
\text { mengatur tempat duduk penumpang } \\
\text { sehinga tidak terjadi keolengan pada saat } \\
\text { di perjalan dan mengingatkan tidak } \\
\text { mengeluarkan kaki ke laut pada saat } \\
\text { perjalanan }\end{array}$ & & \\
& 2. $\begin{array}{l}\text { Petugas pulau pasumpahan menyambut } \\
\text { tamu yang datang dengan ramah dan sopan }\end{array}$ & 0.461 & \\
& 3. $\begin{array}{l}\text { Guide pulau pasumpahan selalu memandu } \\
\text { tamu-tamu nya pada saat di butuhkan }\end{array}$ & 0.371 & Valid \\
4. $\begin{array}{l}\text { Pemilik perahu selalu bercerita tentang } \\
\text { keindahan pulau pasumpahan sambil } \\
\text { mengemudi }\end{array}$ & 0.569 & Valid \\
\hline Sumber : Pengolid
\end{tabular}


Berdasarkan tabel 7 dapat dilihat bahwa semua item pernyataan dinyatakan valid karena $r$ tabel pada semua item pernyataan $r$ kritis berada diatas 0.30 . Sehingga semua item tidak ada yang dihilangkan.

Tabel 8

Uji Validitas Variabel Bebas Proses $\left(\mathbf{X}_{6}\right)$

\begin{tabular}{clcc}
\hline Variable & \multicolumn{1}{c}{ Pernyataan } & Uji Validitas & Keterangan \\
\hline Proses & 1. Jalur akses kepulau pasumpahan sangat & 0.408 & Valid \\
& $\begin{array}{l}\text { dekat } \\
\text { 2. Setelah sampai kedermaga pengemudi } \\
\text { bot langsung meminta izin ke petugas } \\
\text { pulau pasumpahan }\end{array}$ & 0.569 & Valid \\
& $\begin{array}{l}\text { 3. Setelah meminta izin ke kepetugas, } \\
\text { pengemudi bot langsung melaporkan } \\
\text { jumlah penumpang nya kepetugas pulau } \\
\text { untuk memperoleh tiket masuk }\end{array}$ & 0.411 & Valid \\
& $\begin{array}{l}\text { Saya melihat ada peralatan selam yang di } \\
\text { sewakan kepada pengunjung }\end{array}$ & 0.390 & Valid \\
\hline
\end{tabular}

Sumber : Pengolahan Data primer 2018

Berdasarkan tabel 8 dapat dilihat bahwa semua item pernyataan dinyatakan valid karena $r$ tabel pada semua item pernyataan $r$ kritis berada diatas 0.30. Sehingga semua item tidak ada yang dihilangkan.

\section{Tabel 9}

Uji Validitas Variabel Bebas Bukti Fisik $\left(\mathbf{X}_{7}\right)$

\begin{tabular}{|c|c|c|c|}
\hline Variable & Pernyataan & Uji Validitas & Keterangan \\
\hline \multirow[t]{4}{*}{ Bukti Fisik } & $\begin{array}{l}\text { 1. Keindahan pasir pantai dan riak-riak } \\
\text { gelombang laut yang meberikan } \\
\text { kenyamanan di mata pengunjung }\end{array}$ & 0.530 & Valid \\
\hline & $\begin{array}{l}\text { 2. Kerindangan pohon-pohon yang berada } \\
\text { di sekitar pulau pasumpahan } \\
\text { memberikan kesejukan pada } \\
\text { pengunjung }\end{array}$ & 0.574 & Valid \\
\hline & $\begin{array}{l}\text { 3. Selain berenang ada bukit yang terjal } \\
\text { sehingga bisa melihat keindahan pantai } \\
\text { dan pulau-pulau di sekitar pulau } \\
\text { pasumpahan }\end{array}$ & 0.430 & Valid \\
\hline & $\begin{array}{l}\text { 4. Saya duduk di atas dermaga untuk } \\
\text { melihat ke indahan bawah laut }\end{array}$ & 0.583 & Valid \\
\hline
\end{tabular}

\section{Sumber : Pengolahan Data primer 2018}

Berdasarkan tabel dapat dilihat bahwa semua item pernyataan dinyatakan valid karena $r$ tabel pada semua item pernyataan $r$ kritis berada diatas 0.30 . Sehingga semua item tidak ada yang dihilangkan.

\section{Uji Realibilitas}

Tabel 10

Ringkasan hasil Analisa Realibilitas Variabel

\begin{tabular}{lccc}
\hline \multicolumn{1}{c}{ Variable } & Jumlah Pernyataan & Croanbach's Alpha & Keputusan \\
\hline Produk & 6 & .703 & Reliabel \\
Harga & 4 & .647 & Reliabel \\
Tempat & 4 & .675 & Reliabel \\
Promosi & 4 & .615 & Reliabel \\
Orang & 4 & .703 & Reliabel \\
Proses & 4 & .661 & Reliable \\
Bukti Fisik & 4 & .737 & Reliable \\
\hline
\end{tabular}


Dari hasil analisis tabel 10 diatas dapat disimpulkan bahwa pada pengujian reliabilitas nilai cronbach alpha pada variable produk, harga, tempat, promosi, orang, proses, bukti fisik dinyatakan reliabel dikarenakan nilai cronbach alpha $>0.60$.

\section{Analisis Deskriptif}

Tabel 11

TCR

\begin{tabular}{ccc}
\hline Variabel & TCR & Keterangan \\
\hline Keputusan Pembelian & 72,71 & Baik \\
Produk & 71,03 & Baik \\
Harga & 69,6 & Baik \\
Tempat & 73,6 & Baik \\
Promosi & 69,7 & Baik \\
Orang & 70,15 & Baik \\
Proses & 70,00 & Baik \\
Bukti Fisik & 72,95 & Baik \\
\hline
\end{tabular}

Sumber: Pengolahan Data Primer, 2018

Dari tabel 11 diperoleh tingkat capaian responden pada variabel keputusan pebelian yaitu 72.71, vaiabel produk yaitu 71.03, variabel harga yaitu 69.6, variabel tempat yaitu 73.6, variabel promosi yaitu 69,7, variabel orang yaitu 70.15, varibel proses yaitu 70.00, dan variabel bukti fisik yaitu 72.95. hal ini dapat dimaknai keseluruhan variabel dengan kategori baik.

Tabel 12

One-Sample Kolmogorov-Smirnov Test

Uji normalitas

\begin{tabular}{lc}
\hline $\mathrm{N}$ & Standardized Resedual \\
\hline Normal Parameter & $\mathrm{a}, \mathrm{b}$ Mean \\
Std. Deviation & 100 \\
Most Extreme DifferencesAbsolute & .0000000 \\
Positive & .96399841 \\
Negative & .110 \\
Kolmogorov-Smirnov Z & .110 \\
Asymp. Sig (2-tailed & -.091 \\
& 1.097 \\
\hline
\end{tabular}

Sumber: Pengolahan Data Primer, 2018

Berdasarkan tabel 12 diketahui bahwa nilai signifikansi $0.180<0.05$ sehingga dapat disimpulkan bahwa data yang di uji berdistribusi tidak normal. 


\section{Uji Heteroskedastisitas}

Tabel 13

Uji Analisis Heteroskedastisitas

\begin{tabular}{ccc}
\hline Variabel & Sig. & Keterangan \\
\hline Produk & .872 & Tidak Heteroskedastisitas \\
Harga & .597 & Tidak Heteroskedastisitas \\
Tempat & .796 & Tidak Heteroskedastisitas \\
Promosi & .733 & Tidak Heteroskedastisitas \\
Orang & .566 & Tidak Heteroskedastisitas \\
Proses & .625 & Tidak Heteroskedastisitas \\
Bukti Fisik & .976 & Tidak Heteroskedastisitas \\
\hline
\end{tabular}

Sumber: Pengolahan Data Primer, 2018

Dari tabel di atas diketahui bahwa gejala heteroskedasitas ditunjukan oleh koefisien regresi variable produk, harga, tempat, promosi, orang, proses, bukti fisik $>0.05$ maka dipastikan hasil uji di atas tidak terjadi gejalan heteroskedasitas.

\section{Uji Multikolinearitas}

Tabel 14

Uji Analisis Multikolinearitas

\begin{tabular}{cccc}
\hline \multirow{2}{*}{ Variabel } & \multicolumn{2}{c}{ Collinearity Statistics } & \multirow{2}{*}{ Keterangan } \\
\cline { 2 - 3 } & Tolerance & VIF & \\
\hline Produk & .596 & 1.678 & Bebas multikolinearitas \\
Harga & .447 & 2.237 & Bebas multikolinearitas \\
Tempat & .421 & 2.377 & Bebas multikolinearitas \\
Promosi & .422 & 2.372 & Bebas multikolinearitas \\
Orang & 462 & 2.162 & Bebas multikolinearitas \\
Proses & .522 & 1.916 & Bebas multikolinearitas \\
Bukti Fisik & .573 & 1.745 & Bebas multikolinearitas \\
\hline Sumber: Pengolahan Data Primer, 2018 & &
\end{tabular}

Dari tabel di atas diketahui bahwa VIF dari variable produk, harga, tempat, promosi, orang, proses, bukti fisik < dari nilai VIF yang ditentukan sebesar 10, sehingga diduga untuk variabel tersebut dalam model regresi tidak terdapat persoalan multikolinearitas.

\section{Analisis Regresi Berganda}

Tabel 15

Uji Analisis Regresi Berganda

\begin{tabular}{|c|c|c|c|c|c|}
\hline \multirow[t]{2}{*}{ Model } & \multicolumn{2}{|c|}{$\begin{array}{c}\text { Unstandardized } \\
\text { Coefficients }\end{array}$} & \multirow[t]{2}{*}{$\begin{array}{c}\text { Standardized } \\
\text { Coefficients }\end{array}$} & \multirow[t]{2}{*}{ T } & \multirow[t]{2}{*}{ Sig. } \\
\hline & $\bar{B}$ & Std.Error & & & \\
\hline (Constant) & 2.737 & 1.896 & & 1.444 & .152 \\
\hline Produk & .022 & .090 & .020 & .245 & .807 \\
\hline Harga & .071 & .145 & .046 & .494 & .623 \\
\hline Tempat & .103 & .146 & .068 & .709 & .480 \\
\hline Promosi & .490 & 151 & .310 & 3.237 & .002 \\
\hline Orang & .304 & .137 & 202 & 2.212 & .029 \\
\hline Proses & .280 & .147 & .164 & 1.906 & .060 \\
\hline Bukti Fisik & .363 & .124 & 240 & 2.927 & .004 \\
\hline
\end{tabular}

Sumber: Pengolahan Data Primer, 2018

$\mathrm{Y}=2.737+0.022 \mathrm{X}_{1}+0.071 \mathrm{X}_{2}+0.103 \mathrm{X}_{3}+0.490 \mathrm{X}_{4}+0.304 \mathrm{X}_{5}+0.280 \mathrm{X}_{6}+0.363 \mathrm{X}_{7}$

1. Hipotesis pertama dalam penelitian ini adalah variable produk berpengaruh positif dan signifikansi terhadap keputusan pembelian. Dengan signifikansi $0,807>0,05$ dan dilihat dari nilai perbandingan antara $t_{\text {hitung }}$ dengan $t_{\text {tabel }}$ 
maka $\mathrm{t}_{\text {hitung }} 0,245<\mathrm{t}_{\text {tabel }} 1,664$. Hal ini berarti $\mathrm{t}_{\text {hitung }}$ lebih kecil dari $\mathrm{t}_{\text {tabel }}$ maka hipotesis $\mathrm{H}_{1}$ ditolak.

2. Hipotesis kedua dalam penelitian ini adalah variable harga berpengaruh positif dan signifikansi terhadap keputusan pembelian. Dengan signifikansi $0,623>0,05$ dan dilihat dari nilai perbandingan antara $t_{\text {hitung }}$ dengan $t_{\text {tabel }}$ maka $t_{\text {hitung }} 0,494<t_{\text {tabel }} 1,664$. Hal ini berarti $t_{\text {hitung }}$ lebih kecil dari $t_{\text {tabel }}$ maka hipotesis $\mathrm{H}_{2}$ ditolak.

3. Hipotesis ketiga dalam penelitian ini adalah variable tempat berpengaruh positif dan signifikansi terhadap keputusan pembelian. Dengan signifikansi $0,480>0,05$ dan dilihat dari nilai perbandingan antara $t_{\text {hitung }}$ dengan $t_{\text {tabel }}$ maka $t_{\text {hitung }} 0,709<\mathrm{t}_{\text {tabel }} 1,664$. Hal ini berarti $\mathrm{t}_{\text {hitung }}$ lebih kecil dari $\mathrm{t}_{\text {tabel }}$ maka hipotesis $\mathrm{H}_{3}$ ditolak.

4. Hipotesis keempat dalam penelitian ini adalah variable promosi berpengaruh positif dan signifikansi terhadap keputusan pembelian. Dengan signifikansi $0,002<0,05$ dan dilihat dari nilai perbandingan antara $t_{\text {hitung }}$ dengan $t_{\text {tabel }}$ maka $t_{\text {hitung }} 3,237>t_{\text {tabel }} 1,664$. Hal ini berarti $t_{\text {hitung }}$ lebih besar dari $t_{\text {tabel }}$ maka hipotesis $\mathrm{H}_{4}$ diterima.

5. Hipotesis kelima dalam penelitian ini adalah variable Orang berpengaruh positif dan signifikansi terhadap keputusan pembelian. Dengan signifikansi $0,029<0,05$ dan dilihat dari nilai perbandingan antara $t_{\text {hitung }}$ dengan $t_{\text {tabel }}$ maka $t_{\text {hitung }} 2,212>t_{\text {tabel }} 1,664$. Hal ini berarti $t_{\text {hitung }}$ lebih besar dari $t_{\text {tabel }}$ maka hipotesis $\mathrm{H}_{5}$ diterima.

6. Hipotesis keenam dalam penelitian ini adalah variable proses berpengaruh positif dan signifikansi terhadap keputusan pembelian. Dengan signifikansi $0,060>0,05$ dan dilihat dari nilai perbandingan antara $t_{\text {hitung }}$ dengan $t_{\text {tabel }}$ maka $t_{\text {hitung }} 1,906>t_{\text {tabel }} 1,664$. Hal ini berarti $t_{\text {hitung }}$ lebih besar dari $t_{\text {tabel }}$ maka hipotesis $\mathrm{H}_{6}$ diterima.

7. Hipotesis ketujuh dalam penelitian ini adalah variable bukti fisik berpengaruh positif dan signifikansi terhadap keputusan pembelian. Dengan signifikansi $0,004<0,05$ dan dilihat dari nilai perbandingan antara $t_{\text {hitung }}$ dengan $t_{\text {tabel }}$ maka $t_{\text {hitung }} 2,927>t_{\text {tabel }} 1,664$. Hal ini berarti $t_{\text {hitung }}$ lebih besar dari $t_{\text {tabel }}$ maka hipotesis $\mathrm{H}_{7}$ diterima.

\section{Uji F}

Tabel 16

Uji Hipotesis F

\begin{tabular}{lccc}
\hline & Model & $F$ & Sig. \\
\hline Regresion & & 23.906 & $.000^{\mathrm{a}}$ \\
Residual & & & \\
Total & & & \\
\hline
\end{tabular}

Sumber: Pengolahan Data Primer, 2018

Berdasarkan hasil uji ANOVA atau F test pada tabel di atas didapatkan Fhitung sebesar 23.906 dengan tingkat signifikansi 0,000. Karena tingkat signifikansi $0,000<0,05$ maka model regresi dapat digunakan untuk memprediksi keputusan pembelian $(\mathrm{Y})$ atau dikatakan bahwa variabel produk $\left(\mathrm{X}_{1}\right)$, harga $\left(\mathrm{X}_{2}\right)$, tempat $\left(\mathrm{X}_{3}\right)$, promosi $\left(\mathrm{X}_{4}\right)$, orang $\left(\mathrm{X}_{5}\right)$, proses $\left(\mathrm{X}_{6}\right)$ dan bukti fisik $\left(\mathrm{X}_{7}\right)$ secara 
bersama-sama atau simultan berpengaruh signifikan terhadap variabel keputusan pembelian (Y).

\section{Analisis Koefisien Determinasi $\left(\mathbf{R}^{2}\right)$}

Tabel 17

R Square

Model Summary

\begin{tabular}{ccccc}
\hline Model & $\mathrm{R}$ & $\mathrm{R}$ Square & $\begin{array}{c}\text { Adjusted R } \\
\text { Square }\end{array}$ & $\begin{array}{c}\text { Std. Error of } \\
\text { the Estimate }\end{array}$ \\
\hline 1 & $.803^{\mathrm{a}}$ & .645 & .618 & 2.86328 \\
\hline
\end{tabular}

Sumber: Pengolahan Data Primer, 2018

Berdasarkan tabel diatas diketahui nilai koefisien korelasi (R) sebesar 0.803. Hal tersebut menunjukkan seberapa besar hubungan antara variabel dependen dalam hal ini bauran pemasaran jasa (produk, harga, tempat, promosi, orang, proses dan bukti fisik) dengan variabel independen keputusan pembelian. Nilai $\mathrm{R}$ sebesar 0,803 menunjukkan bahwa variabel bauran pemasaran jasa (produk, harga, tempat, promosi, orang, proses dan bukti fisik) mempunyai pengaruh terhadap keputusan pembelian sebesar $80.3 \%$

\section{PEMBAHASAN}

\section{Pengaruh Produk terhadap keputusan pembelian}

Dalam penelitian ini adalah variable produk berpengaruh positif dan signifikansi terhadap keputusan pembelian. Dengan signifikansi 0,807 >0,05. Hal ini berarti produk tidakberpengaruh terhadap keputusan pembelian. Sehingga dapat dikatakan bahwa Ho diterima dan Ha ditolak. Sedangkan untuk distribusi frekuensi reliability didapat hasil dari skala TCR rata-rata sebesar 71.03 dalam kategori baik.

Berdasarkan hasil uji ANOVA atau $\mathrm{F}$ test pada tabel 4.27 didapatkan Fhitung sebesar 23.906 dengan tingkat signifikansi 0,000. Karena tingkat signifikansi $0,000<0,05$ maka model regresi dapat digunakan untuk memprediksi keputusan pembelian $(\mathrm{Y})$ atau dikatakan bahwa variabel produk $\left(\mathrm{X}_{1}\right)$ secara bersama-sama atau simultan berpengaruh signifikan terhadap variabel keputusan pembelian (Y).

Saputra,(2013) Produk adalah segala sesuatu yang dapat ditawarkan ke pasar untuk mendapatkan perhatian, di beli, digunakan, atau dikonsumsi yang dapatmemuaskan keinginan atau kebutuhan. Dalam konteks ini, produk bisa berupa apa saja (baik yang berwujud fisik maupun tidak) yang dapat ditawarkan kepada pelanggan potensial untuk memenuhi keinginan dan kebutuhan tertentu. Produk yang bagus juga memiliki keistimewaantambahan yang dibutuhkan oleh konsumen. Bauran produk yang dihadapi pemasar jasa bisa sangat berbeda dengan yang dihadapi pemasar barang.

Penelitian kristiutami (2015) dengan penelitian pengaruh bauran pemasaran terhadap keputusan berkunjung wisatawan di museum geologi bandung dimnana hasil penelitian berpengaruh positif dan signifikan terhadap keputusan berkunjung di museum geologi bandung.

Penelitian Pradita (2012) dengan penelitian pengaruh bauran pemasaran terhadap keputusan berkunjung di objek wisata bukit cinta ambarawa dengan hasil penelitian secara simultan produk, harga, promosi, tempat, people, proses, pelayanan memiliki pengaruh signifikan. 


\section{Pengaruh Harga terhadap keputusan pembelian}

Dalam penelitian ini adalah variable harga berpengaruh positif dan signifikansi terhadap kepuasan nasabah. Dengan signifikansi 0,623>0,05 Hal ini berarti harga tidakberpengaruh terhadap keputusan pembelian. Sehingga dapat dikatakan bahwa Ho diterima dan $\mathrm{Ha}$ ditolak. Sedangkan untuk distribusi frekuensi reliability didapat hasil dari skala TCR rata-rata sebesar sebesar 69.6 dalam kategori baik.

Saputra, (2013)harga adalah jumlah uang yang dibebankan untuk sebuah produk atau jumlah nilai yang konsumen tukarkan untuk mendapatkan manfaat dari memiliki atau menggunakan produk atau jasa. Karakteristik intangible jasa menyebabkan harga menjadi indikator signifikan atas kualitas. Karakteristik personal dan non transferable pada beberapa tipe jasa memungkinkan diskriminasi harga dalam pasar jasa tersebut, sementara banyak pula jasa yang dipasarkan oleh sektor publik dengan harga yang disubsidi atau bahkan gratis. Hal ini menyebabkan kompleksitas dalam penetapan harga jasa. Strategi penentuan harga sangat signifikan dalam pemberian nilai kepada konsumen dan mempengaruhi citra produk, dan keputusan konsumen untuk membeli. Penentuan harga juga berhubungan dengan pendapatan dan turut mempengaruhi permintaan saluran pemasaran. Yang paling penting adalah keputusan dalam penentuan harga harus konsisten dengan startegi pemasaran secara keseluruhan.

Penelitian kristiutami (2015) dengan penelitian pengaruh bauran pemasaran terhadap keputusan berkunjung wisatawan di museum geologi bandung dimnana hasil penelitian berpengaruh positif dan signifikan terhadap keputusan berkunjung d museum geologi bandung.

Penelitian Pradita (2012) dengan penelitian pengaruh bauran pemasaran terhadap keputusan berkunjung di objek wisata bukit cinta ambarawa dengan hasil penelitian secara simultan produk, harga, promosi, tempat, people, proses, pelayanan memiliki pengaruh signifikan.

\section{Pengaruh Tempat terhadap keputusan pembelian}

Dalam penelitian ini adalah variable reliability berpengaruh positif dan signifikansi terhadap kepuasan nasabah. Dengan signifikansi 0,480>0,05 Hal ini berarti reliability tidakberpengaruh terhadap kepuasan nasabah. Sehingga dapat dikatakan bahwa Ho diterima dan $\mathrm{Ha}$ ditolak. Sedangkan untuk distribusi frekuensi reliability didapat hasil dari skala TCR rata-rata sebesar 73.6 dalam kategori baik.

Enzyklopädie, (2015) Tempat atau lokasi adalah sebuah titik tertentu yang dipilih oleh perusahaan untuk melaksanakan segala aktivitas usahanya, dimana titik tersebut mempunyai pengaruhterhadap strategi-strategi usaha dari perusahaan yang bersangkutan. Keputusan ini meliputi keputusan lokasi fisik (misalnya keputusan mengenai dimana sebuah museum atau obyek wisata harus didirikan dan kemudahan akses dalam mencapainya), kenyamanan suatu lokasi dan keamanan kawasan. Selain itu, keputusan mengenai penggunaan perantara untuk meningkatkan aksesbilitas jasa bagi para pelanggan (misalnya, apakah akan menggunakan jasa agen perjalanan ataukah harus memasarkan sendiri paket liburan secara langsung kepada konsumen).

Penelitian kristiutami (2015) dengan penelitian pengaruh bauran pemasaran terhadap keputusan berkunjung wisatawan di museum geologi 
bandung dimnana hasil penelitian berpengaruh positif dan signifikan terhadap keputusan berkunjung d museum geologi bandung.

Penelitian Pradita (2012) dengan penelitian pengaruh bauran pemasaran terhadap keputusan berkunjung di objek wisata bukit cinta ambarawa dengan hasil penelitian secara simultan produk, harga, promosi, tempat, people, proses, pelayanan memiliki pengaruh signifikan.

\section{Pengaruh Promosi terhadap keputusan pembelian}

Dalam penelitian ini adalah variable responsiveness berpengaruh positif dan signifikansi terhadap kepuasan nasabah. Dengan signifikansi 0,002 < 0,05Hal ini berarti Promosi berpengaruh terhadap keputusan pembelian. Sehingga dapat dikatakan bahwa Ho ditolak dan $\mathrm{Ha}$ diterima. Sedangkan untuk distribusi frekuensi empathy didapat hasil dari skala TCR rata-rata sebesar 69.7 dalam kategori baik.

Pinaringsih, (2015)promosi adalah suatu kegiatan yang mengkombinasikan keunggulan produk dan menunjuk konsumen untuk membeli. Meskipun secara garis besar bauran promosi untuk barang sama dengan jasa, promosi jasa seringkali membutuhkan penekanan tertentu pada upaya meningkatkan kenampakan tangibilitas jasa. Selain itu, dalam kasus pemasaran jasa, personal produksi juga menjadi bagian penting dalam bauran promosi.

Penelitian kristiutami (2015) dengan penelitian pengaruh bauran pemasaran terhadap keputusan berkunjung wisatawan di museum geologi bandung dimnana hasil penelitian berpengaruh positif dan signifikan terhadap keputusan berkunjung $\mathrm{d}$ museum geologi bandung.

Penelitian Pradita (2012) dengan penelitian pengaruh bauran pemasaran terhadap keputusan berkunjung di objek wisata bukit cinta ambarawa dengan hasil penelitian secara simultan produk, harga, promosi, tempat, people, proses, pelayanan memiliki pengaruh signifikan.

\section{Pengaruh Orang terhadap keputusan pembelian}

Dalam penelitian ini adalah variable assurance berpengaruh positif dan signifikansi terhadap kepuasan nasabah. Dengan signifikansi 0,029<0,05 Hal ini berarti orang berpengaruh terhadap keputusan pembelian. Sehingga dapat dikatakan bahwa Ho ditolak dan Ha diterima. Sedangkan untuk distribusi frekuensi assurance didapat hasil dari skala TCR rata-rata sebesar 70.15 dalam kategori baik.

Aisyah \& Edwar, (2012)Dalam hubungannya dengan pemasaran jasa “orang" yang berfungsi sebagai penyediajasa sangat mempengaruhi kualitas jasa yang diberikan. Keputusan dalam faktor "orang" ini berarti berhubungan dengan seleksi, pelatihan, motivasi, dan manajemen sumber daya manusia.

Penelitian kristiutami (2015) dengan penelitian pengaruh bauran pemasaran terhadap keputusan berkunjung wisatawan di museum geologi bandung dimnana hasil penelitian berpengaruh positif dan signifikan terhadap keputusan berkunjung d museum geologi bandung.

Penelitian Pradita (2012) dengan penelitian pengaruh bauran pemasaran terhadap keputusan berkunjung di objek wisata bukit cinta ambarawa dengan hasil penelitian secara simultan produk, harga, promosi, tempat, people, proses, pelayanan memiliki pengaruh signifikan. 


\section{Pengaruh Proses terhadap keputusan pembelian}

Dalam penelitian ini adalah variable harga berpengaruh positif dan signifikansi terhadap kepuasan nasabah. Dengan signifikansi 0,060>0,05 Hal ini berarti proses tidakberpengaruh terhadap keputusan pembelian. Sehingga dapat dikatakan bahwa Ho diterima dan Ha ditolak. Sedangkan untuk distribusi frekuensi reliability didapat hasil dari skala TCR rata-rata sebesar sebesar 70.00 dalam kategori baik.

Aisyah \& Edwar, (2012)Proses merupakan gabungan semua aktivitas,yang umumnya terdiri atas prosedur, jadwal pekerjaan, mekanisme, karyawan dan halhal rutin lainnya, dimana jasadihasilkan dan disampaikan kepada konsumen.

Penelitian kristiutami (2015) dengan penelitian pengaruh bauran pemasaran terhadap keputusan berkunjung wisatawan di museum geologi bandung dimnana hasil penelitian berpengaruh positif dan signifikan terhadap keputusan berkunjung d museum geologi bandung.

Penelitian Pradita (2012) dengan penelitian pengaruh bauran pemasaran terhadap keputusan berkunjung di objek wisata bukit cinta ambarawa dengan hasil penelitian secara simultan produk, harga, promosi, tempat, people, proses, pelayanan memiliki pengaruh signifikan.

\section{Pengaruh Bukti Fisik terhadap keputusan pembelian}

Dalam penelitian ini adalah variable responsiveness berpengaruh positif dan signifikansi terhadap kepuasan nasabah. Dengan signifikansi 0,004 <0,05Hal ini berarti Bukti fisik berpengaruh terhadap keputusan pembelian. Sehingga dapat dikatakan bahwa Ho ditolak dan Ha diterima. Sedangkan untuk distribusi frekuensi empathy didapat hasil dari skala TCR rata-rata sebesar 72.95 dalam kategori baik.

Aisyah \& Edwar, (2012) Merupakan suatu hal yang secara nyata ikut mempengaruhi keputusan konsumen untuk membeli dan menggunakan produk layanan yang ditawarkan. Unsur-unsur yang termasuk di dalam fasilitas fisik antara lain lingkungan, dalam hal ini bangunan, peralatan, perlengkapan, petunjuk pelayanan dan barangbarang lainnya yang disatukan dengan service yang diberikan seperti tiket, sampul, label, dan lain sebagainya.

Penelitian kristiutami (2015) dengan penelitian pengaruh bauran pemasaran terhadap keputusan berkunjung wisatawan di museum geologi bandung dimnana hasil penelitian berpengaruh positif dan signifikan terhadap keputusan berkunjung d museum geologi bandung.

Penelitian Pradita (2012) dengan penelitian pengaruh bauran pemasaran terhadap keputusan berkunjung di objek wisata bukit cinta ambarawa dengan hasil penelitian secara simultan produk, harga, promosi, tempat, people, proses, pelayanan memiliki pengaruh signifikan.

\section{SIMPULAN}

Berdasarkan hasil pengujian hipotesis maka dapat ditarik inti kesimpulan daripermasalahan yang dibahas dalam penelitian ini yaitu:

1. Terdapat pengaruh positif dan signifikan antara Produk $\left(\mathrm{X}_{1}\right)$ terhadap keputusan pembelian sebesar 0.245 dan didapat hasil skala TCR rata-rata sebesar $71 . .03$ dengan kategori cukup baik. 
2. Terdapat pengaruh positif dan signifikan antara Harga $\left(\mathrm{X}_{2}\right)$ terhadap keputusan pembelian sebesar 0.494 dan didapat hasil skala TCR rata-rata sebesar 69.6 dengan kategori baik.

3. Terdapat pengaruh positif dan signifikan antara Tempat $\left(\mathrm{X}_{3}\right)$ terhadap keputusan pembelian sebesar 0.709 dan didapat hasil skala TCR rata-rata sebesar 73.6 dengan kategori cukup baik.

4. Terdapat pengaruh positif dan signifikan antara Promosi $\left(\mathrm{X}_{4}\right)$ terhadap keputusan pembelian sebesar 3.237 dan didapat hasil skala TCR rata-rata sebesar 69.7 dengan kategori cukup baik.

5. Terdapat pengaruh positif dan signifikan antara orang $\left(\mathrm{X}_{5}\right)$ terhadap keputusan pembelian sebesar 2.212 dan didapat hasil skala TCR rata-rata sebesar 70.15 dengan kategori baik.

6. Terdapat pengaruh positif dan signifikan antara proses $\left(\mathrm{X}_{6}\right)$ terhadap keputusan pembelian sebesar 2.212 dan didapat hasil skala TCR rata-rata sebesar 70.00 dengan kategori baik.

7. Terdapat pengaruh positif dan signifikan antara proses $\left(\mathrm{X}_{6}\right)$ terhadap keputusan pembelian sebesar 2.927 dan didapat hasil skala TCR rata-rata sebesar 72.95 dengan kategori baik.

\section{UCAPAN TERIMA KASIH}

Dalam menyelesaikan artikel ini, penulis mengucapkan terima kasih sebesar-sebesarnya kepadaBapak Febryandhie Ananda, SE, M.si selaku Ketua STIE-KBP Padang, Ibu Febsri Susanti, SEI, MM selaku Ketua Program Studi Manajemen STIE-KBP Padang, Ibu Aminar Sutra Dewi, SE, M.si selaku pembimbing serta Bapak dan Ibu Dosen beserta staf STIE-KBP yang dengan segala dedikasinya telah memberikan pengetahuan serta bimbingan kepada penulis selama mengikuti perkuliahan.

\section{DAFTAR PUSTAKA}

Aisyah, S. N., \& Edwar, M. (2012). Pengaruh bauran pemasaran jasa terhadap keputusan mengunjungi objek wisata maharani zoo dan goa lamongan.

Andika, A., \& Susanti, F. (2018). Pengaruh Marketing Mix Terhadap Keputusan Pembelian Parfum di Azzwars Parfum Lubeg Padang. https://doi.org/10.31227/osf.io/upgc3

Aziz, N. (2019). Pengaruh Strategi Promosi Terhadap Keputusan Pembelian Yang Dimediasi Oleh Minat Beli Pada Konsumen Restoran KFC Cabang Khatib Sulaiman Padang. https://doi.org/10.17605/OSF.IO/V92TS

Diana, I., \& Dhiba, S. (2014). Analisis pengaruh bauran pemasaran jasa terhadap minat pengunjung paa ibjek wisata museum kesehatan. Ilmu Ekonomi \& Manajemen, 1(1).

Djatikusuma, E. (2014). Analisis Faktor-Faktor Yang Mempengaruhi Keputusan Pembelian Konsumen Pada Produk Minuman Berisotonik Pocari Sweat. Marketing Science, 5, 1-9. 
Enzyklopädie, D. (2015). Pengaruh faktor-faktor kualitas, brand/merek, kemasan, harga, ketersediaan dan acuan terhadap minat beli konsumen, 1-15.

Fernandes, Y. D., \& Marlius, D. (2018). Peranan Customer Service Dalam Meningkatkan Pelayanan Kepada Nasabah Pada PT. Bank Pembangunan Daerah Sumatera Barat Cabang Utama Padang. https://doi.org/10.31227/osf.io/wrh3p

Hafiz, S., \& Dewi, A. S. (2018). Pengaruh Harga Dan Kualitas Produk Terhadap Keputusan Pembelian Konsumen Pada Pengguna Sepeda Motor Pulsar Kawasaki Dikota Padang. https://doi.org/10.31219/osf.io/2ghck

Hidayati, R. R., \& Marlius, D. (2018). Aktivitas Promosi Dalam Meningkatkan Dana Pihak Ketiga Pada PT. Bank Perkreditan Rakyat (BPR) Batang Kapas Pesisir Selatan. https://doi.org/10.31227/osf.io/8dgqn

Jamarnis, S., \& Susanti, F. (2019). Pengaruh Harga Dan Periklanan Melalui Internet Terhadap Keputusan Pembelian Produk Sabun Merek Lux Pada Mahasiswa STIE “KBP” Padang. https://doi.org/10.31227/osf.io/xz3d8

Kusuma, B. A. (2015). Analisis faktor-faktor yang mempengaruhi keputusan pembelian konsumen ponsel merek samsung, 7(3).

Lita, R. P. (2010). Pengaruh Implementasi Bauran Pemasaran Jasa Terhadap Proses Keputusan Wisatawan Mengunjungi Objek Wisata Di Kota Padang, 2(2), 91-99. https://doi.org/10.1017/CBO9781107415324.004

Malardy, M. A., \& Sari, D. (2015). Pengaruh Bauran Pemasaran Jasa Terhadap Keputusan Pembelian Konsumen ( Studi Kasus Konsumen Siete Cafe \& Garden Bandung ) Pemasaran. Jurnal E-Proceeding of Management, 2(2), 1941-1950.

Marlius, D. (2017). Keputusan Pembelian Berdasarkan Faktor Psikologis Dan Bauran Pemasaran Pada PT. Intercom Mobilindo Padang. Jurnal Pundi. Volume 1. No. 1. Hal. 57-66. https://doi.org/10.31575/jp.v1i1.9

Marlius, D. (2016). Pengaruh Bauran Pemasaran Jasa Terhadap Minat Nasabah Dalam Menabung Pada Bank Nagari Cabang Muaralabuh. https://doi.org/10.31227/osf.io/vdqgx

Mayliza, R. (2019). Analisis Keputusan Pembelian Ulang Axis Ditinjau Dari Bauran Pemasaran Kasus Di Kota Padang. https://doi.org/10.31219/osf.io/e7xhy

Pinaringsih, Y. (2015). Pengaruh bauran pemasaran terhadap keputusan berkunjung wisatawan di museum geologi bandung, $I I(2), 77-88$.

Saputra, R. (2013). Analisis implementasi bauran pemasaran jasa akomodasi pada 
hotel new holie pekanbaru, 1-14.

Susanti, F., \& Gunawan, A. C. (2019). Pengaruh Bauran Promosi Dan Harga Terhadap Keputusan Pembelian Produk Kosmetik Maybelline Di Kota Padang. https://doi.org/10.31227/osf.io/npjqh

Susanti, F. (2014). Pengaruh Tarif Iklan Terhadap Pendapatan Pada PT. Radio Swara Carano Batirai Indah Batusangkar. https://doi.org/10.31227/osf.io/dy863

Susanti, F. (2015). Pengaruh Bauran Promosi Terhadap Keputusan Klien Dalam Memilih Radio Carano Sebagai Media Promosi Iklan. https://doi.org/10.31227/osf.io/b9ws7

Wowor, V. R. (2013). Bauran Pemasaran Jasa, Pengaruhnya Terhadap Kepuasan Konsumen Pengguna Mobil Toyota Avanza Veloz PT Hasjrat Abadi Manado. Jurnal EMBA, 1(4), 1229-1239. 